\title{
УСВАЈАњЕ ПЕРИФРАСТИЧНИХ КОНСТРУКЦИЈА У СРПСКОМ ЈЕЗИКУ КАО СТРАНОМ ${ }^{1}$
}

\begin{abstract}
САЖЕТАК
Перифрастични предикатски изрази представљају посебну врсту реченичних јединица које се садржински и формално често не подударају на међујезичком плану (нпр. срп. постићи договор : пољ. dojść do porozumienia : енгл. to reach an agreement). Њихова лексикографска обрада такође је неуједначена и често неадекватна, што студентима којима је српски језик Л2 отежава идентификацију и претраживање у постојећим дескриптивним речницима. Стога, као један од основних задатака теоретичара и практичара у домену наставе страних језика издваја се идентификација оваквих структура и осветљавање њихових значења на основу семантике именичке речи као значењског тежишта тих фраза. Циљ овога рада јесте да се на примерима семантичке скупине глагола са компонентом 'резултативност' /+/ испитају следећи феномени: (а) селекција глаголских лексема и њихових комплемената, (б) предлог за презентацију оваквих спојева у настави српског језика као страног и (в) нацрт њихове лексикографске обраде.
\end{abstract}

КљУЧНЕ РЕЧИ: номинална и вербална компонента, перифрастичне конструкције, српски као страни.

\footnotetext{
${ }^{1}$ Рад је настао у оквиру научноистраживачког пројекта: Синтаксичка, семантичка $и$ прагматичка истраживања (бр. 178004), који се реализује на Филозофском факултету у Новом Саду, уз финансијску подршку Министарства просвете, науке и технолошког развоја. Овај рад изложен је на међународној научној конференцији у Кракову Słowiańskie przyjemności 3: Wielojęzyczność (од 26. до 28. октобра 2018. године).
} 


\section{1. Увод}

Овладавање спонтаним језичким исказом, што природнијим и блиским изворном говорнику, примарни је циљ у процесу учења језика, а перифрастични изрази значајан су сегмент у постизању оваквог циља. Ово je нарочито важно и из угла похрањивања, меморисања језичких информација у процесу учења страног језика. У науци се све више поклања пажња управо истраживањима менталног лексикона која су у корелацији са Синклеровим (Sinclair 1991) учењем о постојању 'принципа слободног избора' насупрот 'принципу целовите конструкције' [Open Choice Principle : Idiom Principle], те претпоставци да у језику постоје 'полуготове целине (блокови)', спремне за усвајање [prefabricates chunks] (Lewis at al. 2000).

Перифрастичне структуре ${ }^{2}$ осветљаване су у оквиру различитих теоријских приступа - синтаксичко-семантички (Wierzbicka 1982), генеративни (Grimshaw and Mester 1988), функционални (Апресјан 2009), когнитивни (Norvig and Lakoff 1987), лексикографски (Kotsyba 2007), статистички, стилски и др. У србистици су се овим феноменом бавили аутори са теоријског и практичног, синхронијско-дијахронијског становишта (Радовановић 1977; Ивић 1980; Петровић 1988; Керкез 1997; Керкез 1998; Пипер 1999; Лазић-Коњик 2006; Бјелаковић 2007; Војновић 2007; Штрбац 2010; Алановић 2013. и др.), као и у оквирима примењених истраживања, превасходно у домену наставе српског језика као страног (Dražić 2014, Ајџановић 2016). Посебан допринос представља истраживање перифрастичних предикатских израза (ППИ) на међусловенским релацијама 3. Тополињске (1982), која је на материјалу пољског, македонског и српског (српскохрватског) језика дала нацрт одреднице хипотетичког општесловенског или двојезичног речника ППИ (на примеру именице пажьа/внимание/uwaga).

Будући да су инвентар синсемантичних глагола и њихови спојеви са номиналном речју непредвидљиви феномени и спадају у идиосинкратичне

2 Када се говори о оваквим спојевима, у србистичкој литератури заступљени су термини декомпоновани предикат (Радовановић 1977; Ивић 1980; Пипер 1999), декомпоновани глагол (Танасић 1995), перифрастични предикатски изрази / перифрастични предикат (Тополињска 1982; Mrazović - Vukadinović 2009; Петровић 1988), аналитички глаголски изрази (Пипер 1999). 
особине језика (Тополињска 1982: 36), предмет овог истраживања јесте испитивање једне групе глагола код којих се у поменутој вези активирају обележја 'процесуалност' и 'резултативност'. Семантичка обележја постизање жељеног циља, остваривање резултата, дакле, активирана компонента терминативности, најтранспарентније су садржана у глаголу доћи, који примарно реферише о савладавању просторних релација и доспевању до одређене границе, те, тако немаркиран, инкорпориран је у семантички садржај осталих глагола ${ }^{3}$ који ће унети компоненте о начину савладавања одређеног пута и информације о броју учесника у процесу досезања циља (постићи сагласност : стећи славу). У ову групу уврштени су глаголи: постићи, стећи, направити, остварити, зарадити, наћи, домоћи се. Ово подразумева одговор на кључно, наизглед једноставно, а у пракси врло комплексно и захтевно питање: како приступити феномену двочланих структура у процесу учења/усвајања и подучавања.

Како би се што обухватније сагледао овај феномен, потребно га је осветлити из различитих углова. Семантички аспект подразумева анализу вербалног и номиналног члана. С једне стране, потребно је идентификовати значењске компоненте примарно пунозначних глагола које се активирају у одређеним спојевима (уп. нпр. постићи договор : наћи решење). Наиме, полази се од хипотезе да функционални глаголи, упркос чињеници да је номинални члан тежиште значења перифразе, нису у потпуности лишени лексичке семантике (Керкез 1997: 303-304, Лазић-Коњик 2006: 233) (уп. нпр. постићи споразум : потписати споразум). С друге стране, када је реч о номиналном члану оваквих веза, важно је утврдити семантичке класе именица које колоцирају са датим глаголом, тј. сагледати њихово значење с обзиром на обележја [апстрактно] : [конкретно], [аутоагентивно] : [коагентивно] и сл. Лексички аспект укључује сагледавање парадигматских релација, односно превасходно реализацију синонимних/блискозначних форми (нпр. резултирати : постићи резултат : остварити резултат). У вези с тим, релевантан индикатор употребе датих спојева, како је у литератури већ констатовано, јесте њихова стилска маркираност, што је у

\footnotetext{
${ }^{3}$ О овоме сведоче и дефиниције глагола наћи, постићи, домоћи се у РМС, као нпр. наћи: 1. а случајно или тражећи доћи у посед чега, угледати или открити кога или што; б. наићи на што (за)добити, прибавити, стећи.
} 
корелацији са стицањем прагматичке компетенције у процесу учења страног језика. Наиме, различити стилови и жанрови захтеваће познавање одређеног лексичког и структурног регистра те је нужно, нарочито неизворном говорнику, предочити очекивана језичко-граматичка средства у нпр. формалном, мање формалном или неформалном исказу.

Педагошки аспект подразумева превасходно идентификацију могућих тешкоћа и грешака у рецепцији и продукцији ових постојаних спојева. С тим циљем спроведена је анкета међу пољским студентима српског језика на универзитетима у Кракову и Вроцлаву, ${ }^{4}$ у којој се, на узорку од дванаест студената на вишим нивоима учења српског језика, проверавају њихове способности да разумеју обједињено значење датих веза, чиме се утврђује степен колокацијске компетенције на овим примерима.

Пред анкетиране студенте постављена су четири задатка.

(1) Првим се проверавало разумевање дате везе тако што се тражио превод на матерњи језик (нпр.: постићи договор, постићи резултат, постићи успех).

(2) У другом задатку тражено је да се искључе неодговарајуће понуђене именице уз дате глаголе (нпр. остварити: договор, снове, идеју, успех, циљ).

(3) У трећем задатку требало је уз дати глагол уписати четири именице које колоцирају с њим.

(4) $\mathrm{y}$ четвртом задатку испитивало се познавање валидне комбинаторике тако што су стубачно дате именице, а у једном реду глаголи - требало је знаком /+/ означити исправну везу.

Циљ једног обухватнијег истраживања подразумевао би да се идентификује колокациони опсег глагола с поменутим обележјима, те да се утврде разлике у њиховим значењима на основу семантике с њима удруживих именица, с тим што би се анализа спроводила из свих наведених аспеката и то за сваки наведени глагол. На тај начин дошло би се до диференцијалних сема посматраних глагола, те до инвентара обележја

\footnotetext{
4 Захваљујемо др Гордани Ђурђев Малкјевич и др Томашу Квоки, који су нам помогли да спроведемо ову анкету.
} 
номиналног члана који се везује за њих, што је у корелацији с правилима њиховог комбиновања и рестрикцијама у том процесу. За потребе овог истраживања испитаће се сви ови аспекти на примерима двају глагола постићи и стећи, будући да се у једном сегменту њихова значења преплићу, a, с друге стране, сваки од њих маркиран је специфичним компонентама, што уноси рестрикцију у колоцирању с номиналним чланом (стећи углед : *постићи углед; стећи образовање : *постићи образовање; *стећи циљ : постићи цииљ). Основне су хипотезе да ће се као диференцијалне црте реализовати следећа обележја: (а) категорија (ко)агентивност; (б) обележје [конкретно+/-]; (в) партиципација евалуатора ситуације; (г) тип ситуације која укључује/искључује однос реципроцитета; (д) параметар (дез)актуализованости у оствареном процесу.

\section{2. Анализа}

\section{1. Глагол постићu}

Како то дефинише РМС, глагол постићи означава активност која подразумева долажење до чега напрезањем, напорима, задобијање онога за чим се тежило. Осим компоненти 'резултативност' и 'процесуалност', како се види већ из дефиниције примарног значења овога глагола, присутно је обележје 'труда, напрезања, напора', чиме се имплицира савладавање извесних препрека у процесу постизања циља. Према подацима из електронског корпуса савременог српског језика овај глагол колоцира са именицама које реферишу о: (а) циљаном усаглашавању двеју или више страна: договор, споразум, сагласност, консензус: Претпоставка је да суy супружници постигли договор (ЕК), Неће ући у владу јер нису постигли сагласност о кандидату за министра (ЕК) и (б) о досегнутом циљу појединца, при чему је у именичку семантику инкорпорирана информација о агенсовом труду, и често је праћена детерминатором, којим се истиче постављени циљ (слава, успех, ефекат, ияиљ; победа, погодак, гол): За то време постигао је светску славу (ЕК), Фасиинирао је слушаоце и читаоче и постигао жељени ефекат ЕК), Он није једини који је постигао успех (ЕК).

\subsection{1. Резултати анкете}

Колокације с глаголом постићи испитиване су у задацима 1, 3 и 4. Резултати показују да се семантика овог функционалног глагола врло 
добро познаје, што се посебно очитује у задатку где се очекивало да се допишу именице које с њим колоцирају. Од укупно 25 именица које су студенти уписали уз дати глагол, ${ }^{5}$ наведено је пет неодговарајућих $(1 / 5$ од укупног броја): награда, свет, срећа, образовање, пораз (и *напредали, што је очигледно грешка на творбеном нивоу), при чему се именице награда, срећа, образовање својом семантиком приближавају очекиваним допунама глагола постићи, с тим што имају додатна обележја (нпр. образоваъе: конкретније: 'циљ', 'труд’, 'усмерење'; концептуализује се као ВРЕДНОст, БОГАТСТВо, те се везује за глагол стећи/стицати).

Четврти задатак пак упућује на то да није једноставно идентификовати понуђене именице које се слажу с глаголом постићи, што потврђују само два исправна и комплетна одговора. У осталим случајевима индикативно је следеће: именице признање (4), решење (3), план (1) идентификоване су као одговарајући колокати глагола постићи, док именице договор (3), сагласност (3), ииљ (1) нису одређене као семантички компатибилне с датим глаголом.

Висок је степен разумевања испитиваних постојаних спојева у задатку где се очекивао преводни еквивалент на матерњем језику. У већини случајева задати спојеви постићи договор/резултат/yсnех преведени су перифразом са глаголом osiagnać (osiagnać porozumienie, rezultat, sukces), peђе са глаголом dojść (dojść do porozumienia). Уочене су пак и друге глаголске лексеме које се у српском језику такође могу употребити, с тим што у дати спој ипак уносе нову нијансу значења: podpisać umowe : потписати договор.

\section{2. Глагол стећu}

Примарно значење глагола $c m e \hbar u$, дато у РМС-у (постати власник чега радом, настојањем), где је у првом плану конкретан ентитет као објекат поседовања (посесум), индукује даље фигуративно и метафорично значење: а. 'постићи нешто, успети у нечему, остварити'. б. 'задобити, заслужити'. Компоненте 'процесуалност', 'рад’, 'резултативност' инкорпориране су у

5 Наведене су следеће именице: успех, ииль, слава, ефекат, резултат, договор, напредак, компромис, ниво, гол. 
семантику именица које колоцирају с глаголом cmeћu, али се диференцирају према следећим обележјима.

(a) Именице с обележјем [конкретно+] - објекти који су резултат ангажмана агенса маркирани су чешће обележјем [живо-]: кућа, иметак, имање, новац, док обележје [живо+] имају именице: пријатељ, познаник, које се концептуализују као вредност до које се долази трудом, настојањем, као и, иако с обележјем [конкретно-], њихови деривати: пријатељство, познанство, где је имплицирана компонента 'реципроцитет' .

(б) Именице с обележјем [конкретно-] диференциране су с обзиром на присуство компоненте 'процена'. (б1) У једну већу групу именица маркираних овим обележјем уврштавају се следеће: наклоност, слава, независност, поверење, популарност, симпатије, поштовање, углед. У споју са глаголом стећи денотира се ситуација сачињена од два актера евалуатора који процењује да се агенсу оправдано приписује какав квалитет: Истакавши да је захваљујући юеговом великом труду и професионализму стекао углед међу својим колегама (ЕК), Стекао је исто тако и Силвијино поверење и убедио је да имам љубавнииу у суседном селу (ЕК). (б2) Другу групу именица карактерише одсуство компоненте 'процена', што искључује партиципацију другог актера (евалуатора) из денотиране ситуације. Овде се убрајају следеће именице: самопоуздағе, уверење, утисак, мишьење, навика, когнитивно-бихејвиоралне семантике: Стекао је нове навике и чудио се како је икад уопите могло друкчије бити (ЕК), Мајстор Франи је брзо стекао одређено мишљење о новом чувару (ЕК), Стекао сам утисак да је у питану нека врста тродимензионалне симфоније (ЕК), Ваљда сам од тог неуспешног пада стекао самопоуздане $(\mathrm{EK})$.

\subsection{1. Резултати анкете}

Везе именица с глаголом стећи (стицати), испитиване такође у задацима 1, 3 и 4, добро се познају, што потврђују резултати добијени у трећем задатку (дописати именице). Од укупно 15 именица које су студенти уписали уз дати глагол, ${ }^{6}$ наведене су само две неодговарајуће:

6 Наведене су следеће именице: знање, новац, искуство, поверење, подрика, пријатељство, наклоњеност, слава, реноме, пријатељ, богатство, вештина. 
ycnex, pemеґе, при чему се обе именице семантиком приближавају очекиваним допунама глагола стећи. У српском језику именица усnех колоцира с глаголом постићи, док се именица решење удружује с глаголом доћи/наћи, чиме је денотирана ситуација која се концептуализује као крајња тачка у процесу, чији се квалитет не може мењати, дезактуализовати.

У највећем броју случајева у преводним еквивалентима задатих спојева стећи искуство, стећи пријатеља, стећи углед употребљени су функционални глаголи zdobyć и zyskać (пољ.) чије је значење блиско српском стећи и могло би се дефинисати као: 'доћи у посед нечега својим залагањем, радом и сл.' ${ }^{7}$ Премда ређи, драгоцени су они примери у којима су испитаници употребили друге глаголске лексеме јер нису очекиване/могуће у датим везама у српском језику. У два случаја уз именицу искуство употребљени су глаголи zebrać и nabrać (пољ.) у чији је семантички садржај укључена сема појачаног интензитета, тј. кумулативности, што имплицира да се радње означене оваквим глаголима концептуализују мултиакционално, тј. као збир радњи које се могу представити центрифугално и у правцу одоздо нагоре (Поповић 2008: 209). Тако би српски еквивалент скупити (накупити) захтевао парцијалне објекте с категоријом [бројиво+]. У српском језику пак комбинаторика глагола скупити (накупити) (пољ. zebrać и nabrać) и именице искуство није очекивана јер дата именица има колективно значење - означава збирно, целовито мноштво појединачних знања, што имплицира нерашчлањивост на саставне делове.

\section{3. Закључак}

Како је показало ово истраживање, семантички сродни функционални глаголи, који активирају своје компоненте тек у споју с именицом, захтевају посебну пажњу кад је у питању њихова позиција у лексичком

\footnotetext{
${ }^{7}$ У пољско-српском речнику (1999) глагол zdobyć дефинисан је на следећи начин: 1. освојити; 2. добити, доћи до чега, изборити се за што; 3. стећи, постићи, освојити; 4. стећи, задобити, освојити; глагол zyskać дефинисан је: 1. зарадити, стећи (добит); добити, искористити; 2. стећи, постићи; добити; 3. придобити, приволети, привући на своју страну.
} 
систему, што има импликације на лексикографску и педагошку праксу. Према речима 3. Тополињске овакве везе (ППИ) „представљају посебну врсту реченичних јединица - непредвидљиве су у истом смислу у којем су праве лексеме, те их стога треба сваку појединачно изучавати" (Тополињска 1982: 39). Будући да представљају један високо организован, граматички изграђен део речника (уп. исто: 39), најприкладније би било предочити ову проблематику из лексикографске перспективе (ауторка сугерише да би најцелисходније било израдити један општесловенски или више двојезичних речника ППИ), при чему би требало узети у обзир горенаведена обележја која диференцирају значења глагола и номиналне компоненте. С обзиром на то да је нама у фокусу усвајање перифрастичних структура у настави српског језика као страног, закључци ће бити изложени у две целине: (а) издвајање диференцијалних црта компонената споја, које би биле основни елементи речничког чланка; (б) утврђивање основних потешкоћа при изради задатака анкете као индикатора онога што треба усвајати и како треба усвајати везане структуре, поштујући полазишта лексичког приступа М. Луиса (Lewis 2000): „Сачинити више од већ постојећег знања и то увек у контексту (нпр. постоји претпоставка да студенти знају везу постићи цииљ, али не и постићи договор, споразум, сагласност и сл.)".

(a) Табела 1: Издвајање диференцијалних црта компонената споја

\begin{tabular}{|c|c|c|c|c|c|}
\hline & \multirow{2}{*}{\begin{tabular}{|l}
$\mathrm{V}$ \\
семантичке \\
компоненте \\
\end{tabular}} & \multicolumn{2}{|c|}{$\begin{array}{l}\mathrm{N} \\
\text { диференцијална обележја }\end{array}$} & \multirow{2}{*}{\multicolumn{2}{|c|}{\begin{tabular}{|l|}
$\begin{array}{l}\text { Ситуација } \\
\text { диференцијална обележја }\end{array}$ \\
ПЕСитуације (дез)актуал.
\end{tabular}}} \\
\hline & & (ко)агентивност & конкретно+/- & & \\
\hline Постићи & $\begin{array}{l}\text { процес } \\
\text { (‘доћи') } \\
\text { труд, напор, } \\
\text { резултат } \rightarrow\end{array}$ & $\begin{array}{l}\text { коагентивност } \\
\text { договор } \\
\text { споразум, } \\
\text { сагласност } \\
\text { консензус }\end{array}$ & $\begin{array}{l}\text { [конкретно-] } \\
\text { висок степен }\end{array}$ & & \\
\hline & (ODet) & $\begin{array}{l}\text { агентивност } \\
\text { слава } \\
\text { успех } \\
\text { ефекат } \\
\text { циљ; } \\
\text { победа } \\
\text { погодак } \\
\text { гол }\end{array}$ & [конкретно-] & [процена-] & $\begin{array}{l}\text { [дезактуализација- } \\
\text { ] }\end{array}$ \\
\hline
\end{tabular}




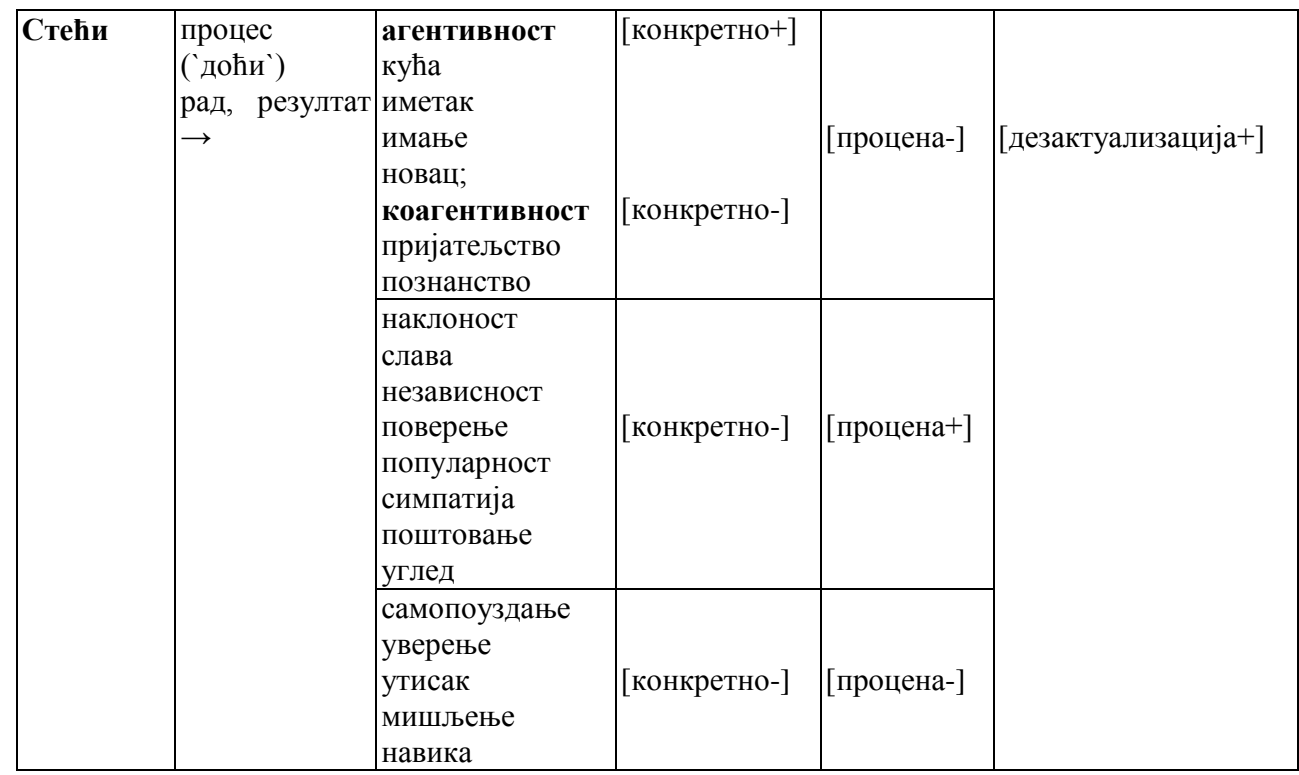

На основу увида у резултате анкете, може се закључити следеће.

(1) Познавање перифраза код студената којима српски језик није матерњи а чији је језик типолошки близак српском, показало се као врло захтеван сегмент усвајања вокабулара, тј. оних бинарних лексичких јединица које функционишу као једна лексема.

(2) Будући да су анкетирани студенти виших година студија српског језика, очекивано је да успешност у решавању задатака буде висока, с тим што ће овај степен варирати у зависности од типа задатка.

(3) Најбољи резултати постигнути су у задатку (бр. 3) у којем се очекивало да се уз дати глагол наведу компатибилне именице, што се може објаснити претпоставком да у менталном лексикону студената постоје похрањени спојеви који се разумеју као једна лексичка јединица. Испитаници су заправо наводили само до тада усвојене спојеве.

(4) Мање успешно испитаници су давали одговоре у задацима (бр. 2 и 4) у којима се проверавала валидна комбинаторика понуђених глагола и именица. Ово би се могло објаснити тиме што су понуђене именице уз дате глаголе семантички сродне, често 
диференциране само једним обележјем. Наведено је индикатор тога на који начин треба усвајати овакве спојеве, тј. путоказ наставницима да треба узети у обзир горенаведена диференцијална семантичка обележја.

(5) Овакво непознавање диференцијалних црта вербалне и невербалне компоненте бинарних спојева одражава се и на способност давања прецизног преводног еквивалента, што се захтевало у првом задатку анкете. Један мањи број одговора упућује на то да се добијени спој разликује од очекиваног у незнатној мери, али довољној да га диференцира на семантичком, функционалностилском и прагматичком плану (постићи споразум : потписати споразум).

\section{ЛИТ Е Р А Т У Р А}

Ајџановић, Јелена (2007). Лексичко-граматичка перифраза модалних глагола (синхроно-дијахрони план). Научни састанак слависта у Вукове дане. 37/1: $127-137$.

Ајџановић, Јелена (2016). Модални глаголи и њихови перифразни еквиваленти у настави српског језика као страног. Српски као страни језик у теорији и пракси. III: 51-61.

Алановић, Миливој (2013). Типични структурно-семантички модели перифраза са глаголима просторно-мобилних односа. Зборник Матице српске за филологију и лингвистику. LVI/2: 39-59.

Бјелаковић, Исидора (2007). Декомпоновање предиката у новинским и административним текстовима 19. и 20. века (смена модела). Научни састанак слависта у Вукове дане. 36/1: 341-357.

Војновић, Јелена (2007). Семантички разлози смене појединих декомпонованих конструкција у новинским и административним текстовима 19. и 20. века. Научни састанак слависта у Вукове дане. 36/1: 325-341.

Ивић, Милка (1980). Још о декомпонованом предикату. Јужнословенски филолог. 44: $1-5$.

Керкез, Драгана (1997). Глаголски конституент перифрастичних предикатских конструкција (у српском и руском језику). Српски језик. 1-2: 303-310.

Керкез, Драгана (1998). Номинални конституент перифрастичних предикатских конструкција. Славистика. II: 93-98.

Лазић-Коњик, Ивана (2006). Структура, функција и лексикографска обрада перифрастичних предиката. Зборник Матище српске за филологију и лингвистику. XLIX/1: 219-304. 
Петровић, Владислава (1988). О перифрастичном предикату са глаголом чинити у Његошевом језику. Научни састанак слависта у Вукове дане. 18/2: 507-513.

Пипер, Предраг (1999). Аналитички глаголски изрази и декомпоновани предикати типа 'изразити захвалност'. Зборник Матице српске за филологију $u$ лингвистику. XLII: 37-43.

Пољско-српски речник. Stownik polsko-serbski. Београд: Српска академија наука и уметности. Одбор за израду чешко-српског и пољско-српског речника Завод за уџбенике и наставна средства.

Поповић, Људмила (2008). Језичка слика стварности: когнитивни аспект, контрастивне анализе. Београд: Филолошки факултет.

Радовановић, Милорад (1977). Декомпоновање предиката. На примерима из српскохрватског језика. Јужнословенски филолог. 33: 53-80.

Речник српскохрватскога књижевног језика. Нови Сад: Матица српска.

Танасић, Срето (1995). Декомпоновање глагола и структура просте реченице. Јужнословенски филолог. 51: 157-166.

Тополињска, Зузана (1982). Перифрастични предикатски изрази на међусловенским релачијама. Јужнословенски филолог. 38: 35-50.

Штрбац, Гордана (2010). Глаголске перифразе са значењем комуникативних делатности. Зборник Матице српске за филологију и лингвистику. LIII/2: 7788.

Apresjan, Jurij (2009). The Theory of Lexical Functions: An Update. In: Proceedings of the Fourth International Conference on Meaning-Text Theory. (eds. D. Beck, K. Gerdes, J. Milićević \& A. Polguère). Montréal: OLST: 1-13.

Dražić, Jasmina (2014). Glagol imati kao konstituent glagolske perifraze u srpskom jeziku. Jezici i kulture u vremenu i prostoru. III: 749-758.

Grimshaw, Jane and Armin Mester (1988). Light Verbs and $\theta$-Marking. Linguistic Inquiry. 19/2: 205-232.

Kotsyba, Natalia (2007). Semantics of light verbs in lexicographical presentation. In: Proceedings of the international conference 'Modern Problems of Lexicography' held in Grodno, Belarus, 19-21 October 2007. Retrieved from: http:// http://domeczek.pl/ natko/papers/ nk__GrodnoX07.pdf

Lewis, Michael (ed) (2000). Teaching collocation. Further Developments in the Lexical Approach. Hove, England: Language Teaching Publications.

Mrazović, Pavica i Zora Vukadinović (2009). Gramatika srpskog jezika za strance. Sremski Karlovci: Izdavačka knjižarnica Zorana Stojanovića.

Norvig, Peter and George Lakoff (1987). A study in lexical network theory. BLS 13: 195205. 
Sinclair, John (1991). Corpus, concordance, collocation. Oxford: Oxford University Press. Wierzbicka, Anna (1982). Why can you 'have a drink' when you can't *have an eat? Language. 58/4: 753-799.

Jasmina Dražić i Jelena Ajdžanović

\section{ACQUIRING PERIPHRASTIC CONSTRUCTIONS IN SERBIAN AS A FOREIGN LANGUAGE}

\section{SUMMARY}

Periphrastic predicative expressions present a special type of sentential units which usually do not coincide on a cross-language level either by their contents or their form (e.g. Serbian nостићи договор: Polish dojść do porozumienia : English to reach an agreement), which makes their acquisition difficult for students of Serbian as a foreign language. Therefore, one of the main tasks of the theorists and practitioners in the domain of foreign language teaching is the identification of such structures, as well as the explanation of their meaning according to the semantics of the noun as the semantic focus of the phrase. The aim of this paper is to explore, by using two verbs - acquire and reach the following phenomena: (a) the selection of verbal lexemes and their complements, (b) the proposal for a presentation of such pairs in teaching Serbian as a foreign language and (c) an outline of their lexicographical treatment.

KEYWORDS: nominal and verbal component, periphrastic constructions, Serbian as a foreign language.

Др Јасмина Дражић

Одсек за српски језик и лингвистику Филозофски факултет, Универзитет у Новом Саду Србија jasmina@ff.uns.ac.rs

Др Јелена Ајџановић Одсек за српски језик и лингвистику Филозофски факултет, Универзитет у Новом Саду Србија jelena.ajdzanovic@ff.uns.ac.rs 